\title{
The analysis of the termination of pregnancies at and after ten weeks of gestation - a monocenter study
}

\author{
Şafak Yılmaz Baran' (iD, Songül Alemdaroğlu' (iD), Gülşen Doğan Durdağ ${ }^{1}$ (D) , \\ Hakan Kalaycı' ${ }^{1}$ iD , Zerrin Yılmaz Çelik ${ }^{2}$ \\ ${ }^{\prime}$ Clinic of Gynecology and Obstetrics, Adana Dr. Turgut Noyan Application and Research Hospital, Başkent University, Adana, Turkey \\ ${ }^{2}$ Department of Medical Genetics, Ankara Hospital, Faculty of Medicine, Başkent University, Ankara, Turkey
}

\begin{abstract}
Objective: We aimed to manage the termination of pregnancies, which were performed at and after 10 weeks of gestation in our clinic, better and to develop appropriate approaches for them by investigating the indications and obstetric characteristics of these cases.

Methods: The maternal data, obstetric characteristics and indications of 379 cases whose termination procedures were performed in our clinic between January 2012 and January 2019 were evaluated. The indications were grouped as maternal reasons, amniotic fluid anomalies, and isolated structural, multiple congenital and genetic disorders. The groups were classified according to their characteristics and they were compared among each other.

Results: The mean age was $30.2 \pm 6$, the mean week of gestation was $17.4 \pm 3.5$, and mean termination duration was $16.4 \pm 14.5$ hours. The most common reason for termination was amniotic fluid anomalies $(\mathrm{n}=126,33.2 \%)$. Among fetal reasons, the most common one was isolated structural anomalies $(\mathrm{n}=114,30.1 \%)$. The anomalies of central nervous system were the most common isolated structural anomalies $(\mathrm{n}=60,15.8 \%)$. Of 379 termination cases, $25(6.6 \%)$ were caused by maternal reasons. The rates of requesting invasive examination for genetic disorders and of performing the examination were $49.6 \%$ $(\mathrm{n}=197)$ and $31.7 \%(\mathrm{n}=120)$, respectively. Chromosomal anomalies were found in $69(18.2 \%)$ cases, with trisomy 21 being the most common anomaly $(\mathrm{n}=39,55.7 \%)$. It was found out that chromosomal anomalies were identified in more advanced maternal ages and at earlier weeks of gestation. On the other hand, isolated structural and multiple congenital anomalies (cardiac and urogenital anomalies in particular) were identified at younger ages and further weeks of gestation (maternal age, $\mathrm{p}=0.002$; week of gestation, $\mathrm{p}<0.001$ ).

Conclusion: The analysis of fetal and maternal reasons and termination complications in the management of termination cases will serve as an example for the management of diagnosis and termination processes of following pregnancies. We believe that considering the ethical, psychological and legal aspects of the terminations of pregnancies will be beneficial in developing standard approaches for this matter with the help of collaboration between families and physicians.
\end{abstract}

Keywords: Termination of pregnancy, prenatal screening, fetal anomaly.
Özet: On hafta ve üzeri gebelik terminasyonlarının analizi - Tek merkezli çalışma

Amaç: Kliniğimizde yapılmış olan 10 hafta ve üzeri gebelik terminasyonlarının endikasyonlarını ve obstetrik özelliklerini inceleyerek, bu olguları daha iyi yönetebilmeyi ve doğru yaklaşımları geliştirebilmeyi amaçladık.

Yöntem: Ocak 2012 - Ocak 2019 arasında kliniğimizde gerçekleşmiş 379 terminasyon olgusunun maternal verileri, obstetrik özellikleri ve endikasyonları değerlendirildi. Endikasyonlar; maternal nedenler, amniyotik sıvı anomalileri, izole yapısal, çoklu konjenital ve genetik bozukluklar olarak gruplandırıldı. Gruplar özelliklerine göre sınıflandırıldı ve kendi aralarında karşılaştırıldı.

Bulgular: Ortalama yaş $30.2 \pm 6$, ortalama gebelik haftası $17.4 \pm 3.5$, ortalama terminasyon süresi $16.4 \pm 14.5$ saatti. En sik amniyotik s1v1 anomalileri nedeniyle terminasyon yapıldığı izlendi $(n=126$, \%33.2). Fetal nedenler içerisinde en sik izole yapisal anomaliler $(\mathrm{n}=114, \% 30.1)$ tespit edildi. Santral sinir sistemi anomalileri en çok görülen izole yapısal anomaliler idi $(\mathrm{n}=60, \% 15.8)$. Terminasyonların 25/379'u (\%6.6) maternal nedenli idi. Genetik bozukluklar için invaziv tetkik istenme oranı \% $49.6(\mathrm{n}=197)$, yapılma oranı \%31.7 ( $\mathrm{n}=120)$ idi. En sık trizomi $21(\mathrm{n}=39, \% 55.7)$ olmak üzere kromozomal anomali 69 (\% 18.2) olguda tespit edildi. Kromozomal anomalilerin daha ileri maternal yaş ve daha erken gebelik haftalarında tespit edildiği izlendi. İzole yapısal ve çoklu konjenital anomalilerin ise daha genç yaşta ve daha ileri gebelik haftalarında saptandığı görüldü (özellikle kardiyak ve ürogenital anomaliler) (maternal yaş, $\mathrm{p}=0.002$; gebelik haftası, $\mathrm{p}<0.001$ ).

Sonuç: Terminasyon olgularının yönetiminde fetal ve maternal nedenlerin ve terminasyon komplikasyonlarının analizi, takip eden gebeliklerin tanı ve terminasyon süreçlerinin yönetiminde örnek olacaktır. Gebelik terminasyonlarının etik, psikolojik, ekonomik ve yasal boyutlarının dikkate alınması, aile ile hekim işbirliği içerisinde bu konuda standart yaklaşımların oluşturulmasında etkili olacağ görüşündeyiz.

Anahtar sözcükler: Gebelik terminasyonu, prenatal tarama, fetal anomali.

Correspondence: Şafak Yilmaz Baran, MD. Clinic of Gynecology and Obstetrics, Adana Dr. Turgut Noyan Application and Research Hospital, Başkent University, Adana, Turkey. e-mail: safakyilmazbaran@gmail.com / Received: January 28, 2019; Accepted: April 22, 2019

Please cite this article as: Yılmaz Baran Ş, Alemdaroğlu S, Doğan Durdağ G, Kalaycı H, Yılmaz Çelik Z. The analysis of the termination of pregnancies at and after ten weeks of gestation - a monocenter study. Perinatal Journal 2019;27(1):14-21. doi:10.2399/prn.19.0271003 


\section{Introduction}

Today, the improvements in ultrasonography and genetic field increase the prenatal diagnosis rates of fetal malformation. Therefore, the termination of pregnancy is offered to patients more frequently as an option. This approach may also introduce some medical, ethical and legal issues. ${ }^{[1,2]}$ In Turkey, termination of pregnancy can be performed upon the request of families in pregnancies which are below ten weeks of gestation in accordance with the law no. 2827. ${ }^{[3]}$ At ten weeks of gestation and above, without any upper limit, termination procedure can be carried out by reasoned reports including objective results in maternal factors which may risk the maternal life or in chromosomal or congenital anomalies which may cause serious fetal outcomes. ${ }^{[4]}$

Our aim in this study is to manage the termination of pregnancies, which were performed at and after 10 weeks of gestation in our clinic, better and to develop appropriate approaches for them by investigating the indications and obstetric characteristics of these cases.

\section{Methods}

A total of 379 termination cases, which underwent their termination procedures in the Perinatology Clinic of Adana Application and Research Center at Başkent University between January 2012 and January 2019, were analyzed by years retrospectively. By using the computer system records of our hospital (Nucleus version 9.3.39; Monad Yazılım ve Danışmanlık, Ankara, Turkey), the pregnancies terminated at 10 or higher weeks of gestation due to maternal or fetal indications were evaluated. Age, gravida and parity, weeks of gestation, delivery method (spontaneous/assisted reproductive technologies), number of pregnancy (singleton/twin) and, if any, karyotype assessments of the pregnant women who underwent termination were recorded. The period up to termination, hospitalization duration, presence and number of previous uterine surgery, balloon procedure for cervical dilatation, hysterectomy frequency, hemorrhage complications after curettage, and the frequency of intracavitary balloon procedure were found.

Termination indications were separated into two groups as maternal and fetal reasons. Fetal reasons were classified as multiple congenital anomalies, isolated structural anomalies, amniotic fluid anomalies and genetic disorders. The genetic disorders were separated into 2 sub-groups as chromosomal anomalies and hereditary gene disorders (sickle cell anemia, thalassemia). The terminations before 14 weeks of gestation were determined as first trimester and at and after 14 weeks of gestation as second trimester. In addition, early and late terminations were determined as before and after 23 weeks of gestation, respectively.

Amniotic fluid anomalies were primarily separated into two groups as cases developing anhydramnios associated with preterm premature rupture of membranes (PPROM) and clinical chorioamnionitis cases. Clinical chorioamnionitis diagnosis is established by at least one of the following findings in addition to maternal fever $\left(38^{\circ} \mathrm{C}\right)$ : malodorous / purulent cervical drainage during speculum examination, uterine sensitivity during abdominal examination, maternal tachycardia $(>120$ bpm), persistent fetal tachycardia ( $>160 \mathrm{bpm})$, leucocytosis $\left(>15,000 / \mathrm{mm}^{3}\right)$, and C-reactive protein $>5 \mathrm{mg} / \mathrm{L}$. In our clinic, pathological assessment of placental material is performed routinely in the cases which undergo termination due to amniotic fluid anomaly. The cases diagnosed with chorioamnionitis were identified histologically. In accordance with these assessments, amniotic fluid anomalies were categorized under three groups which are PPROM-anhydramnios, clinical chorioamnionitis and clinical-histological chorioamnionitis.

Fetal deaths and pregnancies before 10 weeks of gestation were excluded from the study. Chorionic villus sampling or karyotype assay by amniocentesis were recommended for the cases considered necessary. Microarray and whole exome sequencing were recommended beginning from 2017 for all patients whose karyotype analysis results were normal. Microarray was performed only in one patient due to its cost; however, no result was obtained in that patient. The cases whose karyotype analysis results were normal, whose karyotype analysis did not yield any result or those whose families did not want karyotyping were evaluated apart from the chromosomal anomaly group.

The distribution of fetal anomalies according to maternal age, week of gestation, gravida and parity was analyzed by Kruskal-Wallis test while the distribution of fetal anomalies according to delivery type and fetus number was analyzed by chi-square test. SPSS (Statistical Package for the Social Sciences, Chicago, IL, USA) 21.0 was used. In all tests, the statistical significance level was considered 0.05 . 
Termination indication was decided by the committee in our clinic which included three specialists and some physicians from other branches in necessary cases. As termination protocol, $400 \mu \mathrm{g}$ vaginal misoprostol (Cytotec; Ali Raif, İstanbul, Turkey) was administered with 3-hour intervals. Misoprostol administration doses and intervals were arranged individually in accordance with the clinical guidelines by considering obstetric and clinical characteristics such as week of gestation and history of uterine surgery. ${ }^{[6,7]}$

In cases which are at and above 23 weeks of gestation (late termination cases), termination procedure was initiated after performing intrauterine feticide. Intrauterine feticide procedure was performed by administering 2 cc $7.5 \%$ potassium chloride $(\mathrm{KCl})$ after reaching fetal cardiac cavity via 22 Gauge $120 \mathrm{~mm}$ spinal needle with the help of transabdominal ultrasonography.

In cases which were non-responsive to misoprostol, dilatation was performed by intracervical Foley catheter. Aspiration curettage was performed in cases which were found to have rest material after abortion. Hysterectomy was performed in cases which were nonresponsive to induction or had uterine rupture complication.

Post-termination hemorrhages were taken under control by inflating intracavitary Foley catheter with physiological saline solution (about $80 \mathrm{cc}$ ). In cases with higher weeks of gestation and uterine volumes, post-partum hemorrhage could only be taken under control by Bakri balloon (Cook Women's Health Spencer, Bloomington, IN, USA).

The consents of all patients related with the procedures to be performed were obtained.

This study was approved by the Medicine and Health Sciences Research Committee of Başkent University (project no. KA18/329).

\section{Results}

It was seen that 507 termination cases occurred and the reason for 128 cases was fetal death during a seven-year period. In our study, mean age was $30.2 \pm 6$ (range: 15-52), median gravida was 2 (range: $1-7$ ), median parity was 1 (range: $1-5$ ), and mean week of gestation was 17.4 \pm 3.5 (range: 10-27.6) weeks. Mean termination duration was $16.4 \pm 14.5$ (range: $1-120$ ) hours and mean hospitalization was 2 (range: 1-13) days. In terms of termination durations, there was no difference between the groups $(\mathrm{p}=0.114)$. Of the pregnancies, 356 (93.9\%) were singleton and $23(6.1 \%)$ were twin. The number of pregnancies conceived by assisted reproductive technologies was 45 (11.9\%). One hundred pregnancies $(26.4 \%)$ had previous history of uterine surgery. Mean termination duration was $16.6 \pm 14$. 4 hours in the cases which did not undergo uterine surgery while it was $15.8 \pm 15.2$ hours in the cases which underwent uterine surgery $(\mathrm{p}=0.67)$. In addition, the termination procedure was completed in 24 hours in 162 $(80 \%)$ cases with unscarred uterine and in $78(81.3 \%)$ cases with scarred uterine $(\mathrm{p}=0.50)$.

The termination procedure was performed after 23 weeks of gestation (late termination) in 24 (6.3\%) patients. In these cases, termination procedure was carried out after performing feticide by intracardiac potassium with the help of ultrasonography.

The dilatation was carried out by intracervical Foley catheter in $25(6.6 \%)$ patients who were nonresponsive to misoprostol and the termination was performed. The terminations were completed in 44.7 hours by intracervical Foley procedure. It was found that hysterotomy was performed in $1(0.26 \%)$ patient due to uterine rupture associated with misoprostol and in $2(0.79 \%)$ patients due to induction failure. Hemorrhage was taken under control by Foley catheter due to uterine atony in 3 patients who underwent abortion. It was found that the vaginal hemorrhage which developed in $9(3.2 \%)$ patients who had higher weeks of gestation and uterine volume was taken under control by applying Bakri tamponade in uterine. It was found that all pregnancies which underwent Bakri balloon and hysterotomy were at second trimester ( $>15$ weeks of gestation).

Mean termination periods and durations according to the termination indications are given in Table 1. Of 379 termination cases, $25(6.6 \%)$ were caused by maternal reasons (Table 2). The distribution of terminations is given in Fig. 1. Amniotic fluid anomalies were the most common fetal reasons $(n=126,33.2 \%)$. They were grouped as PPROM-anhydramnios (without detecting any additional anomaly in the ultrasound screening) ( $\mathrm{n}=57,45.6 \%)$, clinical chorioamnionitis $(\mathrm{n}=10,8 \%)$ and clinical-histological chorioamnionitis $(\mathrm{n}=58,46.4 \%)$. Of the cases with amniotic fluid anom- 
Table 1. Mean termination periods and durations according to the termination indications.

\begin{tabular}{lccc} 
& & Termination week (week) & Termination duration (hour) \\
\cline { 3 - 4 } & N (\%) & $\begin{array}{c}\text { Mean } \pm \text { SD } \\
\text { (minimum-maximum) }\end{array}$ & $\begin{array}{c}\text { Mean } \pm \text { SD } \\
\text { (minimum-maximum) }\end{array}$ \\
Maternal reasons & $25(\% 6.6)$ & $17.0 \pm 4.5(10-23)$ & $17.3 \pm 12.3(6-48)$ \\
Amniotic fluid anomalies & $126(\% 33.2)$ & $18.2 \pm 3(12-24)$ & $14.2 \pm 14.5(1-120)$ \\
Multiple congenital anomalies & $36(\% 9.5)$ & $18.0 \pm 4.2(12-27)$ & $22.3 \pm 18.3(2-72)$ \\
Genetic disorders & $78(\% 20.6)$ & $15.6 \pm 3.1(11-24)$ & $15.1 \pm 11.9(3-56)$ \\
Isolated CNS anomalies & $60(\% 15.8)$ & $18 \pm 4.2(11-26)$ & $17.9 \pm 15.4(4-80)$ \\
Isolated cardiac anomalies & $14(\% 3.7)$ & $19 \pm 2.6(14-22)$ & $21.1 \pm 14(4 v 54)$ \\
Isolated urinary anomalies & $22(\% 5.8)$ & $19.1 \pm 2.6(15-23)$ & $14.5 \pm 13.2(2-48)$ \\
Isolated skeletal anomalies & $9(\% 2.4)$ & $16.4 \pm 3(13-20)$ & $12.6 \pm 7(5-22)$ \\
Hydrops fetalis & $9(\% 2.4)$ & $15.4 \pm 2.6(12-20)$ & $20.1 \pm 17.8(5-52)$ \\
Total & 379 & $17.4 \pm 3.5(10-27.6)$ & $17.4 \pm 3.5(1-120)$ \\
\hline
\end{tabular}

CNS: Central nervous system; SD: Standard deviation.

alies, 9 were late termination ( $>23$ weeks of gestation), and 4 of them were performed by clinical chorioamnionitis diagnosis and 5 of them were performed by clinical and histological chorioamnionitis diagnosis.

Table 2. The distribution of terminations carried out by maternal indications.

\begin{tabular}{lc} 
Maternal indications & $\mathbf{N}=\mathbf{2 5}(\%)$ \\
\hline Malignities & $11(\% 44)$ \\
Endocrinological reasons & $4(\% 16)$ \\
(diabetes mellitus, thyroid disorders) & \\
Use of teratogenic drugs & $3(\% 12)$ \\
HELLP syndrome & $3(\% 12)$ \\
Cardiac problems & $2(\% 8)$ \\
(atrial septal defect, mitral stenosis) & $1(\% 4)$ \\
Major depression & $1(\% 4)$ \\
Severe preeclampsia & \\
\hline
\end{tabular}

HELLP syndrome: Hemolysis, elevated liver enzymes and thrombocytopenia.

Table 3. The distribution of anomalies found in cases which underwent invasive prenatal analysis.

\begin{tabular}{lc} 
& $\mathbf{n}(\%)$ \\
\hline Trisomy 21 & $39(\% 50)$ \\
Trisomy 18 & $14(\% 18)$ \\
Trisomy 13 & $2(\% 2.6)$ \\
Triple X & $3(\% 3.8)$ \\
Monosomy X & $8(\% 10.3)$ \\
Sickle cell anemia & $9(\% 11.5)$ \\
Other & $3(\% 3.8)$ \\
Total & 15,000 \\
\hline
\end{tabular}

Isolated fetal structural anomalies were detected in $114(30.1 \%)$ cases. Among the isolated fetal anomalies, central nervous system (CNS) anomalies were the most common ones $(n=60,15.8 \%)$. Of 397 cases, invasive examination was requested for 197 (49.6\%) cases and it was performed in $138(34.8 \%)$ cases. Chromosomal anomaly was found in $69(53.9 \%)$ out of 128 cases which underwent karyotype analysis. The distribution of genetic disorders found in the cases which underwent invasive prenatal assay is shown in Table 3.

The distribution of termination indications at first and second trimesters during seven years beginning from 2012 is given in Table 4. It was observed that terminations associated with genetic disorders were the most common during the first trimester. It was seen that isolated anomalies could be diagnosed mostly during the second trimester. It was found that there was an increase in the rates of terminations associated with maternal indications in the last year, and that the rates of amniotic fluid anomalies tended to decrease over the years $(\mathrm{p}=0.001)$.

While chromosomal anomalies were observed in more advanced maternal ages, multiple congenital anomalies and isolated CNS anomalies were more common in younger maternal ages $(\mathrm{p}<0.001)$. Chromosomal anomalies and hydrops were identified at early weeks of gestation while cardiac and urogenital anomalies were identified at further weeks of gestation $(\mathrm{p}<0.001)$. In pregnancies with multiple congenital anomaly, median gravida and parity were lower than the other groups $(\mathrm{p}<0.001)$. 
The rates of amniotic fluid anomalies were higher in multiple pregnancies and the pregnancies conceived by assisted reproductive technologies (independent from being multiple pregnancy) $(\mathrm{p}<0.05)$. The incidence of cardiac anomalies $(27.3 \%)$ and amniotic fluid anomalies $(16 \%)$ was statistically higher in pregnancies conceived by assisted reproductive technologies $(\mathrm{p}=0.04)$.

\section{Discussion}

The most common reason for termination was amniotic fluid anomalies (33.2\%) in our clinic. Amniotic fluid anomalies frequently develop in association with underlying PPROM. Histological chorioamnionitis is identified almost $70 \%$ of PPROM cases. In the presence of clinical or suspected chorioamnionitis, delay in the decision for termination may increase maternal morbidity. ${ }^{[8,9]}$ In our series, we found histological chorioamnionitis in $46.4 \%$ of PPROM cases.

Excluding amniotic fluid anomalies, isolated structural anomalies $(\mathrm{n}=114,30.1 \%)$ and CNS anomalies among them were the most common ones in line with the literature..$^{[1,410-14]}$ Also, Down syndrome is the leading indication in the terminations with chromosomal anomaly indication, which is consistent with the literature. ${ }^{[1,12,14,15]}$ This can be explained with the higher rate of diagnosing trisomy 21 in the countries carrying out national screening program during first trimester as in Turkey. ${ }^{[12,16]}$ Vaknin et al. performed karyotype assay in $71.4 \%$ of their cases in their study while this rate was

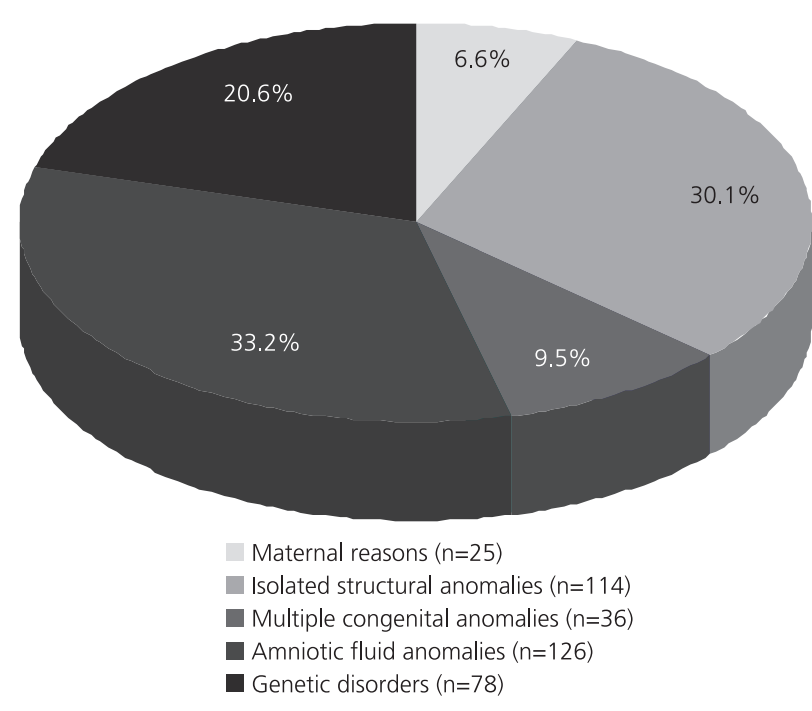

Fig. 1. The diagram view for the distribution of terminations.

$29.6 \%$ in our study group. Lower rate of diagnosing chromosomal anomalies in our study may be associated with the low rate of performing karyotype analysis. ${ }^{[13]}$

The rate of late terminations is $13.2-34.6 \%$ in the literature. ${ }^{[17,18]} \mathrm{We}$ found that the rates of late terminations ( $>23$ weeks of gestation) were quite low $(6.6 \%)$ in our study group. In addition, all of 3 hysterotomy and 12 intrauterine balloon procedures in our series were in second trimester. One of our cases with recurrent cesarean (3 CS) which was at 21 weeks of gestation

Table 4. The distribution of terminations by trimesters and years.

\begin{tabular}{|c|c|c|c|c|c|c|c|c|c|c|c|c|c|c|c|}
\hline & \multicolumn{2}{|c|}{2012} & \multicolumn{2}{|c|}{2013} & \multicolumn{2}{|c|}{2014} & \multicolumn{2}{|c|}{2015} & \multicolumn{2}{|c|}{2016} & \multicolumn{2}{|c|}{2017} & \multicolumn{2}{|c|}{2018} & \multirow{2}{*}{$\frac{\text { Total }}{\text { n (\%) }}$} \\
\hline & 1st tri & 2nd tri & 1st tri & 2nd tri & 1st tri & 2nd tri & 1st tri & 2nd tri & 1st tri & 2nd tri & 1st tri & 2nd tri & 1st tri & 2nd tri & \\
\hline Maternal reasons & - & 2 & & 4 & - & 2 & 1 & 4 & 2 & 2 & 1 & - & 5 & 3 & $26(6.8 \%)$ \\
\hline Amniotic fluid anomalies & 1 & 23 & - & 9 & - & 11 & 1 & 32 & 4 & 22 & 2 & 13 & - & 7 & $125(33 \%)$ \\
\hline Multiple congenital anomalies & - & 5 & 2 & 3 & 2 & 4 & 3 & 3 & 2 & 3 & 1 & 5 & - & 3 & $36(9.5 \%)$ \\
\hline Genetic disorders & 4 & 8 & 9 & 9 & 3 & 9 & 2 & 5 & 5 & 7 & 1 & 7 & 4 & 5 & $78(20.6 \%)$ \\
\hline Isolated CNS anomalies & - & 12 & 1 & 11 & 1 & 4 & 4 & 1 & 2 & 4 & 4 & 5 & 3 & 8 & $60(15.8 \%)$ \\
\hline Isolated cardiac anomalies & - & 2 & - & 4 & - & 2 & - & 2 & - & - & - & 2 & - & 2 & $14(3.7 \%)$ \\
\hline Isolated urinary anomalies & - & 4 & - & 11 & - & 1 & - & - & - & 1 & - & 1 & - & 4 & $22(5.8 \%)$ \\
\hline Isolated skeletal anomalies & - & 1 & - & - & 1 & 1 & - & - & 1 & 2 & 1 & - & - & 2 & $9(2.4 \%)$ \\
\hline Hydrops fetalis & - & 1 & 1 & 1 & - & 2 & 2 & - & - & 2 & - & - & - & - & $9(2.4 \%)$ \\
\hline Total & \multicolumn{2}{|c|}{$63(16.6 \%)$} & \multicolumn{2}{|c|}{$65(17.2 \%)$} & \multicolumn{2}{|c|}{$43(11.4 \%)$} & \multicolumn{2}{|c|}{$60(15.8 \%)$} & \multicolumn{2}{|c|}{$59(15.5 \%)$} & \multicolumn{2}{|c|}{$43(11.4 \%)$} & \multicolumn{2}{|c|}{$46(12.1 \%)$} & 379 \\
\hline
\end{tabular}

CNS: central nervous system; tri: trimester (1st trimester: $<14$ weeks, 2 nd trimester: $\geq 14$ weeks). 
underwent hysterotomy associated with uterine rupture at 12 th hour. Additionally, two cases, one of which was at 22 weeks of gestation and had recurrent CS and the other one at 23 weeks of gestation with previous history of CS, underwent hysterotomy due to non-responsiveness to induction (dilatation by misoprostol + intracervical Foley catheter balloon) at 50th and 120th hours of induction, respectively $(0.79 \%)$. In another study investigating 263 cases in our region reported 6 hysterotomy procedures (caused by induction failure in 4 cases, HELLP syndrome in 1 case and uterine rupture in 1 case) $(2.28 \%) .{ }^{[19]}$ In the literature, the rates of hemorrhage, blood transfusion, infection, post-procedure placenta retention, uterine rupture, hysterotomy and hysterectomy complications were reported higher in second trimester terminations than first trimester terminations, independent from all risk factors. ${ }^{[20]}$

Yapar et al. compared Bishop score $\leq 4$, extra-amniotic ethacridine lactate in terminations conducted between 4 and 28 weeks of gestation, intracervical prostaglandin, E2 gel, IV concentrated oxytocin, vaginal misoprostol and balloon procedure in 340 cases in their study. Being unable to complete termination procedure in 48 hours was considered as a failure, and success was achieved in all groups with a success rate of $98.8 \%$. It has been reported that ethacridine lactate, balloon and oxytocin procedures are faster and cheaper methods. Maternal death associated with uterine rupture occurred in a case which underwent oxytocin. It was reported that the extension of induction period in late terminations in particular causes the increase of complications. ${ }^{[21]}$ It is known that prostaglandins are the most effective agents to mature the cervix. ${ }^{[2]}$ There is no sufficient number of studies on the dosage and method of vaginal misoprostol administration during the publication date of the study; we found that the administration of maximum $600 \mu \mathrm{g}$ misoprostol in a total of 36 hours was insufficient compared to other treatment methods. In the termination procedures performed in our clinic, mean vaginal misoprostol administration dose was $1200 \mu \mathrm{g}$.

Yüce et al. evaluated 112 cases of second trimester termination in their recent study, and they administered misoprostol in 50 cases, and used cervical Foley in 32 cases and cervical Foley + single dose of misoprostol in 30 cases. When they compared the methods in terms of efficacy, adverse effects and complications, they observed that the termination duration was significantly shorter in misoprostol group; only the misoprostol group had 2 uterine rupture cases. They claimed that the efficacy increased and complications decreased when misoprostol and intracervical Foley procedure were combined. ${ }^{[23]}$

In another study conducted in Turkey, the authors separated 337 second trimester termination cases with cesarean section history into three groups which were those with cesarean section history for once, twice and more, and the cases had $200 \mu \mathrm{g}$ misoprostol administration intravaginally with 4-hour intervals. Intracervical Foley was applied to the cases which did not undergo termination up to 24 hours. The authors observed no difference among the groups in terms of termination completion period within 24 hours, Foley catheter procedures at the end of 24 hours $(11.9 \%)$ and major complications including uterine rupture. It was reported that Foley catheter procedure in addition to misoprostol was efficient and safe in cases which underwent cesarean. ${ }^{[24]}$ In our studies, 100 cases had cesarean section history. We did not find any significant difference between scarred and unscarred uterines in terms of termination durations.

In their meta-analysis results, Andrikopoulou et al. found similar efficacy for prostaglandin E1, E2 and mechanical methods in second trimester terminations of scarred cases (1 and more cesarean section histories). In their study, the most commonly used cervical agent was prostaglandin E1 analogue (misoprostol), the vaginal termination rate by misoprostol was $96.8 \%$, the termination rate within 24 hours was $76.3 \%$, and the uterine rupture rate was $0.8 \%$. While uterine rupture rates were similar in the cases that were applied prostaglandin E1 and had one cesarean section during their second trimester terminations, there was a slight increase in the uterine rupture risk of those who had two or more cesarean section previously. ${ }^{[2]}$ In our study, the uterine rupture rate was $0.26 \%$ and we did not find any difference in scarred uterines in terms of rupture.

While the clinicians may make termination decision easily in anomalies which are near-fatal or will cause severe disability if the fetus is born, it may be difficult to make termination decision in patient groups which are non-fatal but include additional problems such as trisomy 21 although the opinions of family, podiatrist or physician from relevant field are taken. If the family 
decides to terminate the pregnancy, it should be evaluated carefully if there is any severe malformation that will require the termination of the pregnancy or if it is in compliance with the legal regulations. The delayed terminations in particular may introduce many ethical or medicolegal issues. In addition to the laws of country, many factors such as health system, educational level, cultural characteristics, beliefs and socioeconomic status of families and the sex of fetus have an influence on the termination decision. ${ }^{[1]}$

The Maternal-Fetal Medicine and Perinatology Society of Turkey reported in their Ankara Declaration in 2011 that terminations after 24 weeks of gestation are not ethical. ${ }^{[2,27]}$ Yet, in accordance with the legal regulations, pregnancies can be terminated under necessary conditions without any upper limit for week of gestation in Turkey. Similar to Turkey, there is no upper limit for the termination of pregnancy in some countries such as Austria, Denmark, Belgium, England, Switzerland and Russia. However, some other countries such as Germany, Iran (upper limit is 16 weeks of gestation), Spain and Poland (upper limit is 12 weeks of gestation) limited termination of pregnancy due to medical reasons up to 22 weeks of gestation. In addition, some states of the USA and some European countries defined obligatory legal periods to reconsider the decision after patients are informed about termination by physicians. ${ }^{[28]}$ Turkey does not have such a practice yet. If it is considered that fetus can live after 23 weeks of gestation, neonatal resuscitation and hospitalization at intensive care unit may be decided if it is born alive. Therefore, pregnancy terminations are carried out by performing intrauterine feticide procedure.

\section{Conclusion}

In our series, the most common reason for terminations was amniotic fluid anomalies while isolated fetal anomalies were the second most common reason. Chromosomal anomalies were identified in more advanced maternal ages and at earlier weeks of gestation. We observed that isolated structural (cardiac and urogenital anomalies in particular) and multiple congenital anomalies were identified at younger ages and further weeks of gestation.

We believe that detailed analysis of fetal and maternal reasons in the management of termination cases will be beneficial for both current pregnancy of mother and other following pregnancies. We think that considering the ethical, social, psychological, economic and legal results of the termination of pregnancy and carrying out terminations in collaboration with families and physicians will be effective in developing standard approaches for this matter.

Conflicts of Interest: No conflicts declared.

\section{References}

1. Aslan H, Yildirim G, Ongut C, Ceylan Y. Termination of pregnancy for fetal anomaly. Int J Gynaecol Obstet 2007;99: 221-4.

2. Gitsels-van der Wal JT, Mannien J, Ghaly MM, Verhoeven PS, Hutton EK, Reinders HS. The role of religion in decision-making on antenatal screening of congenital anomalies: a qualitative study amongst Muslim Turkish origin immigrants. Midwifery 2014;30:297-302.

3. 2827 sayılı nüfus planlaması hakkındaki kanun. Resmi Gazete 1983(24 Mayıs);(18059):3-6.

4. Ozyuncu O, Orgul G, Tanacan A, Aktoz F, Guleray N, Fadiloglu E, et al. Retrospective analysis of indications for termination of pregnancy. J Obstet Gynaecol 2018;39:3558.

5. Goya M, Bernabeu A, García N, Plata J, Gonzalez F, Merced $\mathrm{C}$, et al. Premature rupture of membranes before 34 weeks managed expectantly: maternal and perinatal outcomes in singletons. J Matern Fetal Neonatal Med 2012;26:290-3.

6. Dodd JM, Crowther CA. Misoprostol for induction of labour to terminate pregnancy in the second or third trimester for women with a fetal anomaly or after intrauterine fetal death. Cochrane Database Syst Rev 2010;(4):CD004901.

7. ACOG Practice Bulletin No. 135: Second-trimester abortion. Obstet Gynecol 2013;121:1394-406.

8. Linehan LA, Walsh J, Morris A, Kenny L, O’Donoghue K, Dempsey E, et al. Neonatal and maternal outcomes following midtrimester preterm premature rupture of the membranes: a retrospective cohort study. BMC Pregnancy Childbirth 2016; 16:25.

9. Wagner P, Sonek J, Mayr S, Abele H, Goelz R, Hoopmann $M$, et al. Outcome of pregnancies with spontaneous PPROM before $24+0$ weeks' gestation. Eur J Obstet Gynecol Reprod Biol 2016;203:121-6.

10. Corbacioglu A, Aslan H, Aydin S, Akbayir O, Ersan F, Alpay $\mathrm{V}$, et al. Trends in fetal indications for termination of pregnancy between 2002 and 2010 at a tertiary referral center. J Turk Ger Gynecol Assoc 2012;13:85-90.

11. Hern WM. Fetal diagnostic indications for second and thirdtrimester outpatient pregnancy termination. Prenat Diagn 2014;34:438-44. 
12. Tayyar A, Kanber Acar D, Turhan U, Gedik Özköse Z, Ekiz A, Gezdirici A, et al. Late termination of pregnancy due to fetal abnormalities: an analysis of 229 cases. [Article in Turkish] İstanbul Kanuni Sultan Süleyman Tıp Dergisi 2018;10:12-7.

13. Vaknin Z, Ben-Ami I, Reish O, Herman A, Maymon R. Fetal abnormalities leading to termination of singleton pregnancy: the 7-year experience of a single medical center. Prenat Diagn 2006;26:938-43.

14. Vaknin Z, Lahat Y, Barel O, Ben-Ami I, Reish O, Herman A, et al. Termination of pregnancy due to fetal abnormalities performed after 23 weeks' gestation: analysis of indications in 144 cases from a single medical center. Fetal Diagn Ther 2009;25: 291-6.

15. Hamida EB, Ayadi I, Bezzine A, Rabii B, Hammouda SB, Bouguerra B, et al. Termination of pregnancy for fetal anomaly in a Tunisian population. South African Journal of Obstetrics and Gynaecology. 2017;23:69-70.

16. Boyd PA, DeVigan C, Khoshnood B, Loane M, Garne E, Dolk H.; EUROCAT Working Group. Survey of prenatal screening policies in Europe for structural malformations and chromosome anomalies, and their impact on detection and termination rates for neural tube defects and Down's syndrome. BJOG 2008;115:689-96.

17. Guillem P, Fabre B, Cans C, Robert-Gnansia E, Jouk PS. Trends in elective terminations of pregnancy between 1989 and 2000 in a French county (the Isère). Prenat Diagn 2003; 23:877-83.

18. Dickinson JE. Late pregnancy termination within a legislated medical environment. Aust N Z J Obstet Gynaecol 2004;44: $337-41$

19. Cetin C, Buyukkurt S, Seydaoglu G, Kahveci B, Soysal C, Ozgunen FT. Comparison of two misoprostol regimens for mid-trimester pregnancy terminations after FIGO's misopros- tol dosage recommendation in 2012. J Matern Fetal Neonatal Med 2016;29:1314-17.

20. Garofalo G, Garofalo A, Sochirca O, Alemanno MG, Pilloni E, Biolcati M, et al. Maternal outcomes in first and secondtrimester termination of pregnancy: which are the risk factors? J Perinat Med 2018;46:373-8.

21. Yapar EG, Senöz S, Ürkütür M, Batioglu S, Gökmen O. Second trimester pregnancy termination including fetal death: comparison of five different methods. Eur J Obstet Gynecol Reprod Biol 1996;69:97-102.

22. Shepard JH, Knupper RA. The role of prostaglandin in ripening the cervix and inducing labor. Clin Perinatol 1981;8:4962.

23. Yüce T, Yüksel D, Kalafat E, Koç A. Efficacy of secondtrimester termination procedure; medical, mechanic, or combine? Interv Med Appl Sci 2018;10:133-6.

24. Velipasaoglu M, Ozdemir CY, Ozek B, Ayaz R, Tanir HM. Sequential use of Foley catheter with misoprostol for secondtrimester pregnancy termination in women with and without cesarean scars: a prospective cohort study. J Matern Fetal Neonatal Med 2018;31:677-81.

25. Andrikopoulou M, Lavery JA, Ananth, CV, Vintzileos AM. Cervical ripening agents in the second trimester of pregnancy in women with a scarred uterus: a systematic review and metaanalysis of observational studies. Am J Obstet Gynecol 2016; 215:177-94.

26. Örgül G, Soyak B, Aydın E, Tanaçan A, Çă̆an M, Beksaç MS. 22 haftayı geçemeyen gebelikler. Jinekoloji-Obstetrik ve Neonatoloji Tip Dergisi 2017;14:66-9.

27. Uyumaz A, Avcı Y. Türk Hukuku'nda gebeliğin sonlandırılmas1. İnönü Üniversitesi Hukuk Fakültesi Dergisi 2016;1:579-638.

28. Ozel S, Engin-Üstun Y, Avşar F. Türkiye'de gebelik terminasyonunun yasal durumu. Jinekoloji-Obstetrik ve Neonatoloji Tip Dergisi 2017;14:34-8.

Bu makalenin kullanım izni Creative Commons Attribution-NoCommercial-NoDerivs 3.0 Unported (CC BY-NC-ND3.0) lisansı aracilığıla bedelsiz sunulmaktadır. / This work is licensed under the Creative Commons Attribution-NonCommercial-NoDerivs 3.0 Unported (CC BY-NC-ND3.0) License. To view a copy of this license, visit http://creativecommons.org/licenses/by-nc-nd/3.0/ or send a letter to Creative Commons, PO Box 1866 , Mountain View, CA 94042, USA. 